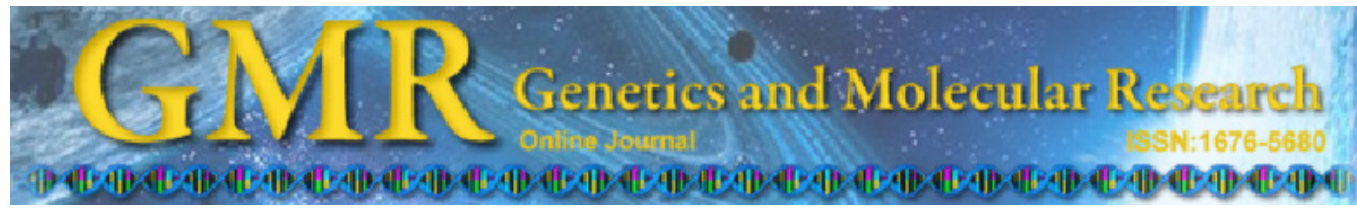

Short Communication

\title{
Isolation and characterization of tetranucleotide repeat polymorphic microsatellite loci in Larus saundersi (Aves, Laridae)
}

H.-X. Jiang', S.L. Ren ${ }^{2}$, Y.-Q. Hou ${ }^{1}$, M. Yang² and X.-B. Wu ${ }^{2}$

${ }^{1}$ Key Laboratory of Forestry Protection of State Forestry Administration, Institute of Forest Ecology, Environment and Protection, Chinese Academy of Forestry, Beijing, China

${ }^{2}$ The Key Laboratory of Biotic Environment and Ecological Safety in Anhui Province, The Key Laboratory of Molecular Evolution and Biodiversity, College of Life Science, Anhui Normal University, Wuhu, China

Corresponding author: Y.-Q. Hou

E-mail: houyq@caf.ac.cn

Genet. Mol. Res. 10 (3): 2034-2037 (2011)

Received November 19, 2010

Accepted May 16, 2011

Published September 12, 2011

DOI http://dx.doi.org/10.4238/vol10-3gmr1164

\begin{abstract}
Nine polymorphic microsatellite loci were isolated, using tetranucleotide repeat oligonucleotide probes from an enriched DNA library of the globally "vulnerable" Saunders's gull (Larus saundersi), collected from the Yancheng coastal wetland, one of the three remaining breeding sites in China. Six breast muscle tissues and 16 blood samples from 22 gulls and eight eggshell membrane tissues were collected for this analysis. The number of alleles per locus ranged from 4 to 15 , with a mean of 8.9. The observed and expected heterozygosities ranged from 0.58 to 0.89 and 0.58 to 0.9 , with means of 0.77 and 0.81 , respectively. No significant linkage disequilibrium and no divergence from Hardy-Weinberg equilibrium were detected among these loci. Based on Micro-Checker tests, no null alleles are present at any of the loci. The microsatellite loci described here will be valuable
\end{abstract}


for exploring population genetic structure and for other relevant genetic studies of Saunders's gull.

Key words: Saunders's gull; Larus saundersi; Microsatellite; Genetic marker; Polymorphism

The globally vulnerable Saunders's gull (Larus saundersi) has a small, declining population occupying highly threatened habitats mainly along the coasts of China, the Korean Peninsula and Japan. In recent years, many efforts were made on population demography, migration pattern, breeding population dynamics, and habitat transition. The current world population is estimated to be a minimum of 14,400 birds, which is more than $70 \%$ higher than the mid-point of the estimated range (7100-9600) according to Wetlands International in 2006. However, the apparent population increase is due to increased survey effort. It is likely that the population is continuing to decline, given the significant threats to habitats and high human disturbance levels occurring across the species' range (Cao et al., 2008). The breeding localities of the species are common seepweed (Suaeda glauca) habitats on the east coast of China and the southwest coast of South Korea. On the east coast of China, the conversion of common seepweed habitats to other habitat types and the expansion of introduced smooth cordgrass (Spartina alterniflora) were the major and direct reasons for the loss and degradation of breeding habitats of Saunders's gull (Jiang et al., 2010).

Separate populations of numerous wide-ranging species are known to exhibit differences in migratory behaviors such as their tendency to migrate, and the magnitude, direction, and timing of their movements (Russell et al., 2005). Phylogeographical studies of many bird species have revealed that differences in migratory behavior are typically correlated with genetic structure among populations (Helbig, 2003). Analyses of the migratory European eel (Anguilla anguilla) indicate significant genetic structuring among regional populations, which may be due to differences in the timing of their use of a common breeding area (Wirth and Bernatchez, 2001). To date, only a few studies have paid attention to the population genetic structure, gene flow and phylogeography of Saunders's gull. Recently, based on mitochondrial control region sequence variation, Jiang et al. (2008) examined the genetic structure of the species, and no distinctive geographic phylogeography was found among the four sub-populations. The application of molecular markers with higher mutation rates, such as highly variable microsatellites, may improve the level of population resolution that is currently attainable with mtDNA analysis. The level of geographical structure expected from microsatellite variation is yet to be determined for the species. In the current study, we first isolated and characterized a set of high polymorphic diversity microsatellites for the species.

Microsatellites were isolated from an enriched library constructed with a minor modified biotin-capture method (Hamilton et al., 1999). Briefly, genomic DNA was extracted from Saunders's gull muscle tissue following a standard phenol-chloroform protocol (Sambrook and Russell, 2001). Initially, 2-4 $\mu$ g genomic DNA were digested with Sau3AI. DNA fragments ranging from 300 to 900 bp were purified from a 1.5\% agarose gel, using a gel extraction column kit (TaKaRa) and ligated to the linkers made by annealing equimolar amounts of Sau-L-A and Sau-L-B. The ligated DNA molecules were then hybridized to single-stranded 5-biotinylated tetranucleotide repeat oligonucleotide probes (including (AAAC), $(\mathrm{ACCT})_{6}$, $(\mathrm{AACT})_{6}$, and $(\mathrm{AGAT})_{6}$ ) and captured with streptavidin-coated beads (Roche). Microsatellite- 
enriched fragments were amplified by polymerase chain reaction (PCR) using Sau-L-A as the primer, and the double-stranded products were ligated to the plasmid pMD18-T vector (TaKaRa). The recombinant plasmid was transformed into DH5 $\alpha$ competent cells. PCR with Sau-L-A and one of the oligonucleotides as primers was employed to identify the transformants. Clones that yielded two or more bands contained microsatellite fractions. In total, 120 positive clones were obtained, and 90 of them were selected and sequenced on an automated ABI 3700 DNA sequencer. Forty-six primer pairs were designed according to the sequence flanking the repeat motifs using Primer Premier 5.0 (http://www.premierbiosoft.com/). Sixteen sets of primers that gave consistent and specific PCR products were tested for allelic polymorphism. DNA from thirty samples (muscle, blood and eggshell membrane tissues), which were collected from Yancheng city in Jiangsu Province, was used as PCR templates to screen allelic polymorphism for each locus. PCR was carried out in a $15-\mu \mathrm{L}$ reaction mixture, including 20-30 ng template DNA, 0.8 U Taq DNA polymerase (TaKaRa), 1.5 $\mu \mathrm{L}$ 10X PCR buffer (TaKaRa), $\mathrm{MgCl}_{2}$ (Table 1), $1.2 \mu \mathrm{L} 20 \mathrm{mM}$ dNTPs, $0.1 \mu \mathrm{L}$ BSA, and $0.3 \mu \mathrm{L} 10 \mathrm{mM}$ of the locus-specific primer. The PCR conditions were as follows: $95^{\circ} \mathrm{C}$ for $5 \mathrm{~min}$, followed by 30 cycles of $30 \mathrm{~s}$ at $95^{\circ} \mathrm{C}, 30 \mathrm{~s}$ at optimized annealing temperatures (Table 1), and $30 \mathrm{~s}$ at $72^{\circ} \mathrm{C}$, and a final extension at $72^{\circ} \mathrm{C}$ for $5 \mathrm{~min}$. Polymorphism investigation was only conducted for those primer pairs giving correct and consistent specific products. Amplification products, loaded on $8.0 \%$ denaturing polyacrylamide gels, were analyzed on a Li-Cor 4200 automated DNA sequencer, with a size standard (50-350 bp, IRDye700 or IRD-800). Gel images were analyzed using the SAGAGT software.

\begin{tabular}{|c|c|c|c|c|c|c|c|}
\hline Locus & Primer sequence $\left(5^{\prime}-3^{\prime}\right)$ & Repeat motif & $T_{\mathrm{a}}$ & Size (bp) & $N_{\mathrm{A}}$ & $H_{\mathrm{O}} / H_{\mathrm{E}}$ & GenBank \\
\hline Lasa-1 & $\begin{array}{l}\text { F: GAGACGCTTGGCGAAAGTG } \\
\text { R: ACTACCAGCACAGACGTGG }\end{array}$ & $(\mathrm{TCCA})_{11} \mathrm{~N}(\mathrm{TCCA})_{7}$ & $60^{\circ} \mathrm{C}$ & $218-236$ & 9 & $0.845 / 0.900$ & HQ424471 \\
\hline Lasa-2 & $\begin{array}{l}\text { F: TTGCAACACCTCCATGCTG } \\
\text { R: CACGCTCAACCTTGCTGG }\end{array}$ & $(\mathrm{TCTA})_{15}$ & $65^{\circ} \mathrm{C}$ & 291-329 & 15 & $0.882 / 0.842$ & HQ424472 \\
\hline Lasa-3 & $\begin{array}{l}\text { F: GATGTCCCACCTGGTCTCC } \\
\text { R: GCCATCTAAGGTACCAATGAGC }\end{array}$ & $(\mathrm{TCTA})_{13} \mathrm{~N}(\mathrm{TA})_{6}$ & $55^{\circ} \mathrm{C}$ & $193-221$ & 8 & $0.800 / 0.842$ & HQ424473 \\
\hline Lasa-4 & $\begin{array}{l}\text { F: TGTGCAGGGAGTGACCTTC } \\
\text { R: TTGCCGTTGTTCTTTCAGC }\end{array}$ & $(\text { TAGT })_{6}$ & $57^{\circ} \mathrm{C}$ & 266-288 & 4 & $0.580 / 0.579$ & HQ424474 \\
\hline Lasa-5 & $\begin{array}{l}\text { F: GGGATTCCACGGTGACAAG } \\
\text { R: AGAGCTATTCAAGACCGCAG }\end{array}$ & $(\mathrm{AAAC})_{6}$ & $57^{\circ} \mathrm{C}$ & 201-217 & 7 & $0.797 / 0.833$ & HQ424475 \\
\hline Lasa-6 & $\begin{array}{l}\text { F: GATGTCCCACCTGGTCTCC } \\
\text { R: TCTTAGAGCCGTGCTGTCC }\end{array}$ & $(\mathrm{TCTA})_{9} \mathrm{~N}(\mathrm{TA})_{6}$ & $58^{\circ} \mathrm{C}$ & $395-423$ & 8 & $0.595 / 0.684$ & HQ424476 \\
\hline Lasa-7 & $\begin{array}{l}\text { F: CCACTCCATCATCCCTAACC } \\
\text { R: TCCCACTTGTGTGAAGACC }\end{array}$ & $(\text { TAGA })_{11}$ & $56^{\circ} \mathrm{C}$ & 170-188 & 9 & $0.791 / 0.824$ & HQ424477 \\
\hline Lasa-8 & $\begin{array}{l}\text { F: CCATGGCAACTCTTCCGC } \\
\text { R: TGCGGATTTGTGCTTTCCC }\end{array}$ & GATA $)_{7} \mathrm{C}(\mathrm{ATAG})_{7} \mathrm{~N}(\mathrm{GT})_{5}$ & $55^{\circ} \mathrm{C}$ & 228-264 & 14 & $0.888 / 0.875$ & HQ424478 \\
\hline Lasa-9 & $\begin{array}{l}\text { F: CAGGTCCAACCCTCTACGC } \\
\text { R: TCCTGCTTTGAGGTAAACAGAAC }\end{array}$ & $\left((\mathrm{AGTT})_{10}\right.$ & $58^{\circ} \mathrm{C}$ & 293-313 & 6 & $0.760 / 0.880$ & HQ424479 \\
\hline
\end{tabular}

$T_{\mathrm{a}}=$ annealing temperature; $N_{\mathrm{A}}=$ number of alleles; $H_{\mathrm{E}}=$ expected heterozygosity; $H_{\mathrm{O}}=$ observed heterozygosity.

The Genetix software (Belkhir et al., 1996) was used to determine the number of alleles $\left(N_{\mathrm{A}}\right)$ per locus, and observed $\left(H_{\mathrm{O}}\right)$ and expected $\left(H_{\mathrm{E}}\right)$ heterozygosities. Tests for significant deviation from Hardy-Weinberg equilibrium (HWE) and linkage disequilibrium (LD) were performed using Genepop version 4.0 (Raymond and Rousset, 1995). Micro-Checker version 2.2.3 (Van Oosterhout et al., 2004) was used to identify null alleles. 
In total, nine polymorphic microsatellite loci were isolated in this study. The number of alleles, PCR product size and heterozygosity of these loci are summarized in Table 1. A total of 80 alleles were identified from the 30 samples of the species, and the $N_{\mathrm{A}}$ per locus ranged from 4 to 15 with an average of 8.9. The $H_{\mathrm{O}}$ and $\mathrm{H}_{\mathrm{E}}$ ranged from 0.58 to 0.89 and 0.58 to 0.90 , respectively. No significant LD $(\mathrm{P}<0.05)$ and no HWE $(\mathrm{P}<0.05)$ was detected among these loci. Results of Micro-Checker tests showed that no null alleles may be present at any of the loci. These results showed that the microsatellite loci described here will be valuable in exploring population genetic structure and in other relevant genetic studies of Saunders's gull.

\section{ACKNOWLEDGMENTS}

Research supported by the Department of Wildlife Conservation and Nature Reserves Management, State Forestry Administration of China. We would like to thank Mr. Liu XiaoYun, Mr. Wang Hui and Mr. Sun Guo-Rong for their assistance in obtaining samples.

\section{REFERENCES}

Belkhir K, Borsa P, Goudet J and Bonhomme F (1996). GENETIX: Logiciel Sous Windows Pour La Génétique de Population. Laboratoire Génome et Populations, CNRS UMR 5171, Université de Montpellier II, Montpellier.

Cao L, Barter MA and Wang X (2008). Saunders's Gull: a new population estimate. Bird Conserv. Int. 18: 301-306.

Hamilton MB, Pincus EL, Di Fiori A and Fleischer RC (1999). Universal linker and ligation procedures for construction of genomic DNA libraries enriched for microsatellites. Biotechniques 27: 500-507.

Helbig AJ (2003). Evolution of Bird Migration: A Phylogenetic and Biogeographic Perspective. In: Avian Migration (Berthold P, Gwinner E and Sonnenschein E, eds.). Springer-Verlag, Berlin, 81-95.

Jiang HX, Hou YQ, Qian FW, Chu GZ, et al. (2008). Population genetic divergence and migration pattern of the Saunders's gull Larus saundersi. Acta Zool. Sin. 54: 767-776.

Jiang HX, Hou YQ, Chu GZ, Qian FW, et al. (2010). Breeding population dynamics and habitat transition of Saunders's Gull Larus saundersi in Yancheng National Nature Reserve, China. Bird Conserv. Int. 20: 13-24.

Raymond M and Rousset F (1995). Genepop (version 1.2): population genetics software for exact tests and ecumenicism. J. Hered. 86: 248-249.

Russell AL, Medellin RA and McCracken GF (2005). Genetic variation and migration in the Mexican free-tailed bat (Tadarida brasiliensis mexicana). Mol. Ecol. 14: 2207-2222.

Sambrook J and Russell DW (2001). Molecular Cloning. 3rd edn. Cold Spring Harbor Laboratory Press, New York.

Van Oosterhout C, Hutchinson WF, Wills DPM and Shipley P (2004). Micro-Checker: software for identifying and correcting genotyping errors in microsatellite data. Mol. Ecol. Notes 4: 535-538.

Wirth T and Bernatchez L (2001). Genetic evidence against panmixia in the European eel. Nature 409: 1037-1040. 